\title{
Old Age and Poverty in Developing Countries: New Policy Challenges
}

\author{
PETER LLOYD-SHERLOCK * \\ University of East Anglia, Norwich, UK
}

\begin{abstract}
Summary. - Almost all developing countries are now experiencing demographic ageing. This paper examines the consequences of ageing for the poor. It assesses the extent to which the poor are participating in demographic ageing, or whether the process is largely restricted to relatively privileged groups. The paper observes that policy and research mainly focus on pensions programs, which have little relevance for most poor older people. It then describes livelihood patterns for poor elders, highlighting the importance of intergenerational exchange. Health policies are also found to largely ignore the needs of this group, and the expansion of private financing presents particular problems. (C) 2000 Elsevier Science Ltd. All rights reserved.
\end{abstract}

Key words - older people, poverty, health policy, pensions

\section{INTRODUCTION}

This paper provides a brief overview of demographic trends in developing countries, paying specific attention to relationships between ageing and poverty. It then focuses on particular policy challenges which result from the population ageing process. First, it considers the need to ensure that older people enjoy a satisfactory level of economic well-being, arguing that the high priority given to pension reform in many developing countries has deflected attention away from the economic realities of the poor. The paper goes on to examine health care needs and health policy for the aged. It observes that the current wave of health sector reforms rarely take into account the requirements of older people. Three central themes which inform the discussion are that (a) poor older people are a highly heterogeneous group for whom Western notions of old age often do not apply; (b) that the contexts in which they live are varied and highly dynamic, and (c) that the needs of older people are interlinked and should elicit intersectoral policy responses.

\section{DEFINITIONS, TRENDS AND MEANINGS}

There is general dissatisfaction with defining old age in purely chronological terms, but there would appear to be no universally appropriate alternative to this approach. Old age is perceived and understood in a multitude of different ways, often with important cultural variations. These may refer to biological processes and physical appearance, key life events, or social roles (Apt, 1997; Knopoff et al., 1991; Derricourt \& Miller, 1992). Since old age can cover a span of over three decades, most cultures distinguish between the "old old" and "young old," and it is usually more meaningful to think in terms of a gradual change, rather than a sharp cut-off between adulthood and later life (Feathersone and Werwick, 1995). Social attitudes and media imagery rarely reflect this heterogeneity of old age, and the labeling of elders as frail, dependent and vulnerable is the rule in many countries (Hazan, 1991; Gorman, 1999a). Similarly, international policy debates reflect what might be termed a "negative paradigm of old age," in which older people are seen as uniformly marginal to economic activity and development (Lloyd-Sherlock, 2000a). This partly accounts for the lack of attention given to population ageing in the international agenda and the inappropriate nature of many policies.

\footnotetext{
* I am very grateful to the two anonymous referees whose thoughtful comments made an important contribution to this paper. Final revision accepted: 16 June 2000 .
} 
Demographic ageing (defined as an increase in the percentage of a population aged 65 years old or over) is now an established trend in all world regions, with the exception of Africa (Tables 1 and 2). To date, the process has been much more evident in developed countries. Indeed, projections of population ageing in Asia and Latin America for 2025 predict similar levels to those of Europe back in the 1970s. This does not mean, however, that elderly populations outside the developed world are insignificant: since 1980 more older people have been living in developing than developed regions. In Asia and Latin America, rapid rates of absolute population growth will lead to a threefold increase in over 60 year-olds during 1990-2025, reaching 795 million (Table 3). In much of Africa accelerated life-cycle transitions mean that standard chronological measurements of age understate the true importance of the ageing process (Apt, 1996). Overall population ageing is paralleled by similar increases in the number of very old people (Table 3 ).

Data aggregated at the level of world regions hide important internal variations. Table 4 shows the proportion of older people at the individual country level, selecting countries which represent the extreme range for each world region. Population ageing is usually a consequence of a country passing into the final stage of demographic transition, when sustained drops in fertility occur (Chesnais, 1992). As the number of children being born in the younger cohorts falls, the relative importance of the elderly population increases. This effect is compounded by significant reductions in adult mortality, which contribute to extended life expectancy. Some sub-Saharan African countries are yet to enter the final stage of transition, and it remains uncertain if they ever will (Kirk, 1996). High rates of mortality from HIV/AIDS among younger group may, however, cause a sudden surge in demographic ageing, which is not factored into most current projections (Mupedziswa, 1997).

Care should also be taken when using demographic data aggregated at the level of individual countries, since these often hide significant internal variations (Table 5). Large socioeconomic disparities between rural and

Table 1. Estimated percentage of total population aged 65 years or more by world region $(\%)^{\mathrm{a}}$

\begin{tabular}{lccrrr}
\hline & 1950 & 1960 & 1970 & 1980 & 1990 \\
\hline Europe & 8.2 & 8.8 & 10.5 & 12.4 & 12.6 \\
Africa & 3.2 & 3.0 & 3.1 & 3.1 & 3.1 \\
Asia & 4.1 & 4.2 & 4.0 & 4.4 & 4.9 \\
Latin America and Caribbean & 3.5 & 3.8 & 4.1 & 4.4 & 4.8 \\
\hline
\end{tabular}

${ }^{a}$ Source: United Nations (1994).

Table 2. Median-variant projection of percentage of total population aged 65 years or more by world region ${ }^{\mathrm{a}}$

\begin{tabular}{lrrrr}
\hline & 2000 & 2010 & 2020 & 2030 \\
\hline Europe & 14.5 & 15.5 & 18.0 & 21.4 \\
Africa & 3.2 & 3.3 & 3.8 & 4.6 \\
Asia & 5.7 & 6.5 & 8.2 & 10.7 \\
Latin America and Caribbean & 5.6 & 6.5 & 8.4 & 11.2 \\
\hline
\end{tabular}

${ }^{a}$ Source: United Nations (1994).

Table 3. Population aged 60 years old or over and 70 years or over for world region, 1970-2025 $(000 s)^{\mathrm{a}}$

\begin{tabular}{|c|c|c|c|c|c|c|}
\hline & \multicolumn{2}{|c|}{1970} & \multicolumn{2}{|c|}{1990} & \multicolumn{2}{|c|}{2025} \\
\hline & $60+$ & $70+$ & $60+$ & $70+$ & $60+$ & $70+$ \\
\hline Africa & 18194 & 6265 & 31346 & 11238 & 96592 & 36202 \\
\hline Asia & 138551 & 48694 & 243335 & 92216 & 694380 & 286854 \\
\hline Europe & 59536 & 41815 & 167928 & 96845 & 191717 & 96845 \\
\hline Latin America & 17728 & 6811 & 31849 & 13138 & 100630 & 44190 \\
\hline
\end{tabular}

${ }^{a}$ Source: United Nations (1994). 
Table 4. Countries with highest and lowest proportions of population aged 65 or over by world region, 1990 a

\begin{tabular}{lcc}
\hline Region & Country & $\begin{array}{c}\% \text { population } \\
\text { aged } 65+\end{array}$ \\
\hline Africa & South Africa & 4.3 \\
& Botswana & 2.3 \\
Asia & Japan & 12.0 \\
& Cambodia & 2.6 \\
Europe & Sweden & 17.8 \\
& Albania & 5.3 \\
Latin America & Uruguay & 11.6 \\
& Nicaragua & 3.0 \\
\hline
\end{tabular}

${ }^{a}$ Source: United Nations (1994).

urban areas or between different regions of the same country are usually reflected in demographic variations. On the one hand, richer areas may enjoy higher life expectancy and lower fertility, leading to above-average rates of ageing. This has been the case in Buenos Aires, where $16.3 \%$ of the population were aged 65 years or over in 1991, compared to $8.9 \%$ in Argentina as a whole (INDEC, 1993). On the other hand, the selective out-migration of younger age groups may lead to disproportionate numbers of older people in poor, rural districts. For example, in the impoverished Brazilian state of Paraíba $6.5 \%$ were aged 65 years or over in 1991, compared to $3.6 \%$ in the economic heartland of São Paulo. The relative importance of these counteracting processes may have important effects on subnational patterns of ageing, as well as on the welfare of older people.

In addition to examining overall trends in population ageing, it is important to identify which groups are benefiting most from the process. In Europe and North America there are marked gender effects, with disproportionate numbers of women, especially among the very old (Table 6). The reasons for this imbalance are complex, partly reflecting genetic factors, as well as higher male mortality, through violence and accidents in early adult life and through chronic disease in later adult life. This has led some to refer to the "femini- zation of old age" (Arber and Ginn, 1991). In other world regions, however, the relationship is less apparent (Table 6), and the experiences of individual countries vary widely. For example, in India there were slightly more men aged over 60 than women in 1990. The reasons for these variations are difficult to pin down, although they may reflect the extent of relative socioeconomic disadvantage faced by women in some countries. In the case of India, gender imbalances among the aged are also seen in the structure of the population as a whole. These trends show the danger of assuming that tendencies identified in developed countries will inevitably be repeated in the south.

\section{AGEING AND POVERTY}

Another issue is whether population ageing mainly affects relatively privileged groups, or whether it is occurring across society as a whole, including the poor. Many of the developing countries most affected by population ageing now contain large middle classes. Are these the only groups that are enjoying longer life expectancy? If this is the case, the challenge of meeting the health and other welfare needs of the old will be less severe for the state, since these groups are more likely to have economic assets and other independent means of support. Indeed, in this case, equitable policies should seek to target those groups currently less likely to reach old age rather than older people themselves.

A simple approach would be to compare relative rates of population ageing in poor and richer districts in the same country. But, as mentioned earlier, poor districts may experience net losses of younger age groups through migration, while richer ones may see net gains. More sophisticated analysis requires data combining age and economic status. These are not widely available for developing countries, and it is especially difficult to find information which charts these trends over time. Even

Table 5. Subnational variations of population ageing (population aged 65 or over), c. 1991

\begin{tabular}{lcrcc}
\hline & Region with highest $\%$ & \multicolumn{3}{c}{ Region with lowest $\%$} \\
\hline Argentina, 1991 & Federal Capital & 16.3 & Formosa & 4.7 \\
India, 1991 & Kerala & 6.2 & Assam & 3.1 \\
Thailand, 1990 & Ang Thong & 12.9 & Udon Thani & 5.1 \\
Brazil, 1991 & Paraíba & 6.5 & Roraima & 2.2 \\
\hline
\end{tabular}

a Sources: Gulati and Rajan (1999), INDEC (1999), Government of Thailand (1995), IBGE (1991). 
Table 6. Ratios of men to women for elderly populations by world region, c. $1990^{\mathrm{a}}$

\begin{tabular}{lcc}
\hline & $\begin{array}{c}\text { Aged 60 } \\
\text { or more }\end{array}$ & $\begin{array}{c}\text { Aged 70 } \\
\text { or more }\end{array}$ \\
\hline Africa & 0.84 & 0.78 \\
Asia & 0.93 & 0.83 \\
Europe & 0.64 & 0.51 \\
Latin America and the & 0.86 & 0.80 \\
Caribbean & & \\
\hline
\end{tabular}

${ }^{a}$ Source: calculated from United Nations (1994).

where these data are available, interpretation is hampered by several effects. Data on economic status are mainly based on reported income, but this can be a particularly inappropriate indicator for the aged. For example, a survey from Thailand found that $9 \%$ of people aged 60 or more in 1995 reported receiving no income whatsoever (Chayovan, 1999). The authors take pains, however, to stress that many of this group were not in a particularly poor economic position, as their livelihoods were sustained by nonmonetary support from relatives.

A second problem of interpretation is that income data are usually provided for households, not individuals. As such, it is not possible to capture any potential bias against or in favour of older people in intrahousehold distribution. A survey of rural widows in India using household survey data found no evidence that this group lived in particularly poor households (Dreze \& Srinivasan, 1998). Numerous micro-level studies show, however, that Indian widows are often heavily discriminated against in economic terms within households (Alter Chen, 1998).

A third problem is that changing patterns of old age and poverty may result from two separate processes. The first of these is whether the poor are more or less likely to reach old age than is society as a whole. Second, the extent of old age and poverty reflects the possibility that people may fall into or escape poverty over time. The rapid fall in real pension values in many former socialist and Latin American countries, is likely to have contributed to the impoverishment of older people (Lazcko, 1994; Mesa-Lago, 1994). Conversely, economic growth in Thailand before 1997 saw large income increases for the elderly population, although average income remained considerably below that of other age groups (Chayovan, 1999).

In the absence of appropriate data sets it is not possible to generalise about the extent of poverty among older people compared to other age groups. But, a reduced capacity for income generation and a growing risk of serious illness are likely to increase the vulnerability of elders to fall into poverty, regardless of their original economic status, unless comprehensive and effective social policies are in place. Moreover, community-level studies from several countries suggest that although those born into poverty are less likely to reach old age, an important and growing minority still do so (Chawla, 1996; Lloyd-Sherlock, 1999). Few of these have entitlements to social insurance or have made provision for later life. Indeed, for many of them, a protracted old age may have come as a surprise - something which had not happened to their parents or grandparents. While they may still only account for a small proportion of older people in developing countries, they require the support of specific policy interventions.

\section{PENSIONS AND POOR OLDER PEOPLE}

In both the developed and developing world, research into the economic well-being of older people has largely been subsumed into debates about contributory pension and social security reform. Over the past decade or so, there has been a clear shift away from the orthodoxy that as countries achieved economic "development" they would establish universal, state-run welfare programs providing a variety of services, including old age benefits, and based on principles of solidarity. This has been superseded by a neoliberal doctrine which views old age pensions as a private good, which should be managed through the private sector (ILO, 1992; World Bank, 1994; Barrientos, 1998).

These debates are important, and have many consequences for the fiscal regimes and labour markets of developing countries. Pension schemes often account for a high proportion of public spending, particularly in Latin America (Lloyd-Sherlock, 2000b). But, their relevance to the problems of most older people in most developing countries is questionable. Typically, pension funds only cover a minority of the population, and levels of affiliation in the rural and informal sectors or for women are notoriously low. Table 7 overstates true levels of coverage for older people, as in many countries large numbers of pensioners are from younger age groups. For example, in Turkey, Hungary and Brazil white collar workers are sometimes 
Table 7. Pension fund coverage for selected countries, cerca $1990^{\mathrm{a}}$

\begin{tabular}{lccc}
\hline & & \% labour force covered & Pensioners as \% of over 60s \\
\hline Côte D'Ivoire & 1989 & 9.3 & 5.7 \\
China & 1989 & 23.7 & 22.5 \\
The Philippines & 1990 & 19.1 & 7.0 \\
Brazil & 1989 & 50.3 & 47.1 \\
Peru & 1992 & 25.7 & 17.6 \\
\hline
\end{tabular}

${ }^{a}$ Source: World Bank (1994, pp. 356-360).

entitled to retire as young as 50 or even 40 years old (World Bank, 1994). Moreover, official coverage data have sometimes been criticized for being "overoptimistic" (Mesa-Lago, 1991). In almost every country, pension entitlements require that the individual pay monthly contributions over a minimum period of years. For most of the poor, opportunities to defer consumption in this way are very limited, and so it is unlikely that a system based on contributory principles, be it publicly or privately managed, will succeed in including these groups. The recent wave of neoliberal pension reforms have generally led to reductions of coverage for the poor, due to inceased contribution rates (Mesa-lago, 2000). Moreover, they have entailed high fiscal costs (in the case of Chile, around 5\% of GDP since 1980), drawing on resources which could otherwise have been used to help poor older people.

For those who do receive a pension, the value of the benefit is rarely sufficient to provide an acceptable level of livelihood. In Buenos Aires, which is currently one of the most expensive cities in the world, the value of the basic pension (received by over $90 \%$ of pensioners) was only US\$200 a month in mid-1999. As a result, many pensioners obtain the bulk of their income from other sources. A study of older people living in slum districts of Buenos Aires found that although the majority received some form of state assistance, over three-quarters of these had at least one other significant source of support: $14 \%$ of pensioners in the study relied on weekly food handouts from local churches, and 5\% resorted to scavenging and begging (Lloyd-Sherlock, 1997a).

Nor should it be assumed that old age pensions primarily benefit the aged. Studies from a number of developing countries have shown that income from pensions is often pooled at the household level and younger groups, particularly grandchildren, may receive a large share (Sagner \& Mtati, 1999; Liu Liant $\& \mathrm{Gu}, 1999)$. In poorer households, it is more likely that the pension income will be redis- tributed, and that a guaranteed monthly benefit, even if small, will be significant, given the erratic nature of earnings in the informal or rural sectors. In a qualitative survey in rural South Africa, older people claimed that they spent around three times as much of their monthly pensions on the needs of younger family members as they did on themselves (Mohatle \& Agyarko, 1999).

As such, the tendency to label contributory pension reform as primarily an issue concerned with the livelihoods of older people or of resolving the "old age crisis," is usually misleading in the context of the developing world. Moreover, it has served to stifle and distort research and policy development in areas of more direct relevance to the aged. Many of the issues dealt with in this paper are only just beginning to appear on policy agendas and are very lightly researched, if at all.

A small number of developing countries also provide noncontributory old age benefits. In South Africa pensions are given to all over 65 year-olds and they compare favorably with average earnings (Ferreira, 1999). In Brazil rural workers are entitled to old age pensions funded, in part, by urban contributions (Fernandes, 1995). Urban workers who have not made sufficient payments for a contributory benefit are in theory entitled to a means-tested pension once they reach the age of 70 . Noncontributory pensions in Brazil are less generous than in South Africa, however, and do not meet the basic living needs of older people, especially in the more expensive cities (Lloyd-Sherlock, 1999).

Beyond these two countries, there are few examples of large-scale noncontributory pension programs in Asia, Africa or Latin America. Where noncontributory programs are found, they usually only cover a very small proportion of older people or are of a minimal value. In Argentina, it was estimated that means-tested pensions only reached $5 \%$ of the potentially eligible population in the early 1990s (Lloyd-Sherlock, 1997a). In Thailand, an 
emergency assistance scheme quickly grew to cover 300,000 older people identified by village heads as indigent, but payments were only in the order of US\$8 a month (Knodel, Chayovan, Graiurapong, \& Suraratolecha, 1999). It is usually the case that only the well-informed, mobile and best-connected older people benefit from these limited schemes, and means testing is more often a mechanism of arbitrary rationing rather than systematic targeting (Alter Chen, 1998). Interestingly, in both Argentina and Thailand, the national constitutions make explicit commitments for the state to provide for older people who have no other means of support. It is often difficult, however, for poor older people to prove that they have no alternative forms of assistance (including errant children), and the author is not aware of any legal challenge from elders who felt that their constitutional rights were being abused.

\section{OTHER FORMS OF LIVELIHOOD}

Other than pensions, the forms of economic livelihood pursued by poor older people are varied, reflecting their heterogeneity as a group and the contexts in which they live. Nevertheless, a number of generalizations can be made.

Reported economic participation rates have fallen sharply over recent decades, particularly in Latin America (ILO, 1997). But, the types of activity that older people tend to engage in are often underrepresented in official surveys (Kaiser, 1994; UN, 1991), and levels of activity are especially high for poor elders (LloydSherlock, 1997a; Cain, 1991). Older workers in the urban informal and rural sectors are usually engaged in manual activities, and are likely to experience a gradual process of downgrading in their labor status and earnings over time. Where alternative forms of support are not available, they may be obliged to continue in activities which yield diminishing returns, so long as their health permits (Dharmalingham, 1994). When economic activity involves a family unit, such as on a rural small-holding, it is possible that elders will obtain a position of relative authority in the workplace. In contexts of rural wage labor or the urban informal sector, no such seniority hierarchy is likely to occur, and so older workers will be particularly vulnerable.

In a context of poverty and low pension coverage, it is likely that declines in economic participation in later life are a reflection of reduced opportunities for work rather than a desire to disengage from the laborforce. In some countries these constraints have increased in recent years, as older people have faced stronger intergenerational competition for a shrinking pool of employment opportunities. For example, in most Former Socialist Economies rising unemployment has had a disproportionate impact on the aged: in Slovakia the share of the laborforce composed of people above retirement age fell from 33 to $19 \%$ over 1989-92 (Rein \& Worgotter, 1994). Similarly, falling old age employment rates in Latin America are probably more the result of structural adjustments to the laborforce than the extension of nominal pension entitlements. A number of community-based schemes for poor older people have shown that increasing access to credit, reinforcing existing capabilities and developing new ones, can reduce some of the barriers to economic activity (Gorman, 1999b). As yet, these programs have been mainly instigated by nongovermental organizations (NGOs) and they have not been attempted in significant numbers or on a large scale.

For many poor older people, economic relations with other household or family members are an important, and sometimes the only, source of livelihood (Dharmalingham, 1994; Redondo, 1990). Cultural attitudes to supporting the aged vary. Although women are usually the main providers of care, this responsibility may fall to the younger daughters, daughters-in-law, sisters or some other relation (Ofstedal, Mary Beth, Knodel, John \& Chayoevan, 1999). Reliance on household support tends to increase through later life, and due to a lack of alternative strategies, older women are particularly dependent (LloydSherlock, 1997a; Chayovan \& Knodel, 1997). Consequently, it is important to look at the welfare of older people with reference to the economic position of the households in which they live. A lack of employment opportunities for younger relatives will probably have a greater impact on elders than will targeted state interventions, such as low-value pension benefits.

Household relations are not always one-way and may be best understood within a framework of intergenerational exchange. Older people often make important economic contributions, pooling pension income or wages, or performing tasks such as cleaning and child- 
care, which release other household members for salaried employment (Gorman, 1999b). Effective policies must be based on a good understanding of how intergenerational exchange occurs within poor households. It is sometimes claimed that informal exchange systems are more entrenched in poorer societies than in more developed ones. For example, the World Bank has argued that traditional support systems for older people in sub-Saharan Africa are working "relatively well" (World Bank, 1994, p. 54). This has partly been ascribed to cultural effects and to the resilience of norms of respect for elders in non-Western societies (Contreras de Lehr, 1989; Ikels, 1993). These views are often based, however, more on intuition than on systematic empirical research. It is likely that the rapid pace of economic and social change in much of the developing world will have placed great strains on these exchange mechanisms and will have relegated many elders to an increasingly marginal role. Studies from East Asia have found cases where intergenerational exchange has stood up well to these challenges (Thailand) and cases where it has been less resilient (Hong Kong) (Philips, 2000). More work is needed to identify factors which account for these differences.

The World Bank has argued that, rather than shield older people against the breakdown of intergenerational exchange, formal pension systems actually make things worse. This is because formal systems may crowd out private transfers by reducing the willingness of children to provide additional support (World Bank, 1994, pp. 66-67). But, if intergenerational exchange is based on reciprocity, pension income may provide older people with financial resources which can be offered in return for other goods, such as general care. This may be particularly significant in poor households where other sources of monetary income are limited.

One clear consequence of social and economic change is that growing numbers of older people are living alone or in small household units. It is usually assumed that this increases their economic vulnerability, and this has been confirmed by numerous studies (Dreze, 1990; Grieco \& Araba Apt, 1996). Care should be taken, however, when equating co-residence with household support. A study of slums in Buenos Aires found that aged residents were more likely to receive economic assistance from children who had moved away, rather than from those who remained behind (Lloyd-Sherlock, 1997a). This was because the ability to establish a separate household was a sign of economic success, whereas co-residents were more likely to be unemployed or suffering from health problems. Where housing is scarce, co-residence may reflect a lack of alternatives rather than an ethos of household solidarity. Indeed, overcrowding may lead to a range of problems for the aged including poor sanitation and abuse.

Inheritance rights may have a large effect on patterns of intergenerational exchange. Even when they have little current income, older people often own houses and other valuable assets, such as land. Traditions of inheritance vary around the world: in India, for example, inheritance has traditionally been patrilineal, increasing the vulnerability of elderly widows (Agarwal, 1998). Indian law now recognizes widows' property rights, and there have been a number of cases where these rights were upheld (Agnes, 1999). Traditional structures are more likely to prevail, however, over legal rulings in poorer communities. Studies of slum districts in Latin America found high levels of home ownership among elders, but noted that respondents rarely saw this as an important determinant of intergenerational exchange. This may have been because land tenure rights were not officially recognized and because traditional notions of inheritance had been disrupted by migration from rural areas (Lloyd-Sherlock, 1997a).

The observations made in this section are stylized and do not fully capture the varying characteristics of older people and the different contexts in which they live. Nevertheless, a number of policy lessons can be taken from this review. It is clear that pension policy must be understood within the broader livelihood strategies of older people. These include reduced access to and diminishing returns from labor over time, and rising dependence on intergenerational exchange. Particular attention must be paid to the problems of older women. Policy should build on the contributions already being made by older people, and should increase their capacity to engage in successful livelihood strategies.

\section{AGEING, POVERTY AND HEALTH}

There is a tendency to treat livelihood and health policy for older people in developing countries as largely separate concerns. This division can be seen in both the academic 
literature and in policy debates. Yet the links between the two issues are many and obvious. Health and poverty are strongly related for all age groups, and this relationship may be particularly significant in later life (Hardiman and Midgley, 1989). This section examines the impact of ageing on health systems and the consequences of health care reform for older people in poverty.

The principle impact of population ageing on health care systems is through associated epidemiological changes. In the developed world there is still disagreement about whether increased longevity means an extension of healthy active lives or an extension of morbidity (Fries, 1980; Manton, Corder, \& Stallard, 1997; Sidell, 1995). For other regions, available data do not even allow for an informed debate. It should not be assumed that the epidemiology of older populations in developing countries will match that of their counterparts in richer ones. The developed world has gone through an "epidemiological transition" similar to, and associated with, the demographic one. The main causes of death and illness have shifted from infectious diseases, undernutrition and inadequate hygiene to a post-transition phase, where "diseases of wealth" (including chronic disease, road accidents and stress) are now prominent (Caldwell, 1993; Frenk, Bobadilla, Stern, Frejka, \& Lozano, 1991; World Bank, 1993). In developing countries the situation is often more complex, and is sometimes referred to as "incomplete epidemiological transition" (Londoño \& Frenk, 2000). On the one hand, easily-preventable diseases and poverty-related problems still continue to account for a high share of mortality and morbidity. On the other, emerging "diseases of wealth" have seen rapid increases. Often distinct epidemiological scenarios can be identified between different geographical zones (rural/urban; rich/poor region) and between different socioeconomic groups. As such, many developing countries face a double health challenge.

Given the differences in the broader epidemiological contexts of developed and developing regions, it is to be expected that the health problems of older people will vary between the two. Those living in developing regions face both pre and post-transition risk factors. For relatively wealthy older people living in cities, the latter set of factors may be most significant. But, for poorer old people, particularly those in rural districts, both sets of risk factors may be important. As such, it is dangerous to gener- alize about the health problems of older people across a single country. For example, in the largely poor rural state of Oaxaca in Mexico intestinal infections were the second most important cause of death for elders in 1990, whereas in the richer, more urbanized state of Baja California, they occupied 12th place (Ham-Chande, 1996). In Mexico, as in many other developing countries, there are increasing concerns that population ageing will lead to an explosion of health spending on "costly" chronic conditions (Durán-Arenas, Sánchez, Vallejo, Carreón, \& Franco, 1996). It should be stressed, however, that the health status of older people in regions such as Oaxaca could be greatly improved with relatively low-cost primary health care interventions.

The health status and access to health services of poor older people are strongly influenced by both their age and their condition of poverty, and the two effects often reinforce each other. Unequal access to education has been shown to be a particularly important explanatory factor for health inequalities in both developing and developed countries (AbelSmith, 1994). Since most older people have considerably less formal education than other age groups, it is likely that they will be at a strong disadvantage. Health facilities in poorer regions are rarely on a par with national standards (Mesa-Lago, 1992). A survey of slums districts in São Paulo, Brazil found a significant number of elderly respondents had migrated there from the north east in order to improve access to health facilities (Lloyd-Sherlock, 1999). In sub-Saharan Africa the majority of older people continue to live in rural areas, whose formal health care infrastructure is often rudimentary (Dinotshe Tou and Sandberg, 1994).

Poor older people often face both direct and indirect economic barriers to health services. User fees and co-payments for public health care are now common practice in most developing countries. In theory, these may serve to generate additional revenue or "rationalize" usage. In pratice, they have often been shown to be inequitable, even where exemptions are supposedly in place for vulnerable groups (Russell and Gilson, 1997). A survey from Ghana found that most older people were unaware that they were exempt from paying user fees for services from public hospitals, and that this had greatly reduced access (Ahenkora, 1999). Cost efficiency concerns have also encouraged the adoption of rationing mecha- 
nisms, many of which include specific age criteria. The best known economic evaluation tool-the Disability-Adjusted Life Year (DALY) - contains an overt bias away from the aged towards more "socially productive" cohorts (Paalman, Bekedam, Hawken, \& Nyheim, 1998).

Indirect barriers to health services are particularly significant for poor older people, since ambulance services tend to be minimal. For those requiring an escort, the opportunity costs of lost employment can be significant. Where elders are themselves economically active, their own lost earnings may also be a factor. A study of barriers to the uptake of cataract services in India found that older people were less disposed to seek treatment than other groups were (Fletcher \& Donoghue, 1998). This reflected the low status of the aged in some communities and the misconception that poor vision was a natural consequence of the ageing process.

The financing and organisation of health care systems in many developing countries have undergone processes of rapid reform over the past decade (Cassels, 1995). This has entailed a shift in policy emphasis away from establishing universal primary health care programs, to a focus on personal health services, including the introduction of cost recovery and market mechanisms, cost effectiveness criteria and decentralised provision. Most primary health care programs stress mother and child health issues, and do not pay specific attention to the health needs of older people. There are no signs the current wave of reforms has rectified this, however, and few studies consider their potential impacts on older people, particularly those in poverty (Lloyd-Sherlock, 2000c). Proponents for neoliberal health reforms argue that shortterm pain will lead to supposed benefits for all in the longer term. They should remember that most of today's aged will not live to see any future benefits.

Health reforms must be understood in contexts where structures of state financing and provision are often fragmented and nonuniversal, and where private insurance is an expanding component (World Bank, 1993). This creates particular problems for poor older people. Many social health insurance programs explicitly exclude or limit cover for the poorest, who are forced to rely on inferior publiclyfunded services (Lloyd-Sherlock, 1997b). A study from Mexico found that service utilization rates of insured older people were roughly double those of elders who lacked cover (Borges-Yañez \& Gómez-Dantés, 1998). Poor elders are unlikely to benefit from expanded private health insurance services, since market mechanisms discriminate against the aged and low-income groups through cream skimming (Hsiao, 1995). Private healthcare maintenance organizations have become a major component of Chilean health care financing since 1980, but in 1998 only $3 \%$ of patients were aged 60 or more, compared to $12 \%$ in public hospitals and clinics (Stocker, Waitzhin, \& Iriant, 1999). Similarly, surveys of newly-formed private insurance companies in Russia indicate a strong tendency to discriminate against the aged (Twigg, 1999).

Meeting the long-term care needs of older people, either formally or informally, is not usually seen as a core function of health policy. But, the division between the two is often an arbitrary one. In many developing countries, policy-makers often assume that the supposed resilience of household and community structures reduces the need for institutionalized care. These assumptions are open to question. For example, in Uruguay, despite a Latin culture which places a high value on family solidarity, a higher proportion of older people are living in residential care than is the case in the United States. In most other countries care institutions are mainly run by the private sector and are beyond the financial reach of the poor (Castells, 1992). Where family support is not forthcoming and where residential care is unaffordable or stigmatized, the only option may be to hospitalize older people. This is already a widespread problem in many developing countries and it is likely to worsen.

Effective health policies for poor older people must be placed in an intersectoral framework. Health care provision is essential for the livelihoods of older people, particularly those in employment. In return, the economic well-being of elders influences their nutritional status and accommodation, and hence their exposure to health risks and general health status. It may also affect the ability of older people to travel to health facilities, both in terms of paying for transportation and of providing a cushion against any lost income. A number of less direct effects may also be important. For example, in South Africa, where most poor older people receive noncontributory pensions, there are indications that family members are more likely to invest in the health of the older person in order to ensure the continuity of the 
pension income (Lloyd-Sherlock \& Tollman, 1999). In this case, there may be a tradeoff between expenditure on pensions and health services.

\section{CONCLUSION: NEW POLICY FRAMEWORKS}

This paper has explored a range of policy concerns relating to the needs of poor older people in developing countries, and highlights the general lack of interest in this issue. Little has been done to assess the extent to which poorer groups are included in population aging. Discussion about livelihoods remains strongly focussed on pension programs, which are of little or no significance to most poor elders. No large-scale social policy initiatives have attempted to support the diverse range of livelihood strategies pursed by many older people. Similarly, health policy has largely overlooked the needs of this group. Concerns about reforming social health insurance and the resource implications of increasing chronic disease ignore the fact that most poor elders are excluded from these programs and are also exposed to easily-treated conditions. An increased emphasis on private financing will further marginalize services for the poor.
Effective policies must begin with the recognition that the aged are a heterogeneous group, reflecting both personal characteristics and the varying contexts in which they live. Policy must take these differences into account and avoid formulaic approaches. There is a particular need to challenge Western paradigms of old age, based on notions of retirement, dependence and infirmity. While older people in poverty may face many constraints, they often make significant contributions to the welfare of their own households and communities. Policies should build on this, fostering an ethos of positive intergenerational exchange. Finally, policy for poor older people should take an inclusive, intersectoral approach. There remains a tendency to view pension programs, health care and other social services as separate domains, and to view the welfare needs of elders as separate from those of other groups.

Much could be done to improve the wellbeing of poor elders, without large increases in social expenditure: far less than the sums usually being devoted to more privileged groups of older people. Unless policy priorities change, however, population ageing in developing countries may just mean an extension of privation and misery, rather than an enrichment of lifetime opportunities.

\section{REFERENCES}

Abel-Smith, B. (1994). An introduction to health. Policy, planning and financing. London: Longman.

Agarwal, B. (1998) Widows versus daughters or widows as daughters? Property, land and economic security in rural India. In M. Alter Chen (Ed.) Widows in India. Social neglect and public action (pp. 124-169) London: Sage.

Agnes, F. (1999). Law and women of age. A short note. Economic and Political weekly, 30 October 1999, pp. $51-54$.

Ahenkora, K. (1999). The contribution of older people to development. The Ghana study. Unpublished paper. Help Age International and Help Age Ghana, London.

Alter Chen, M. (1998). Introduction. In M. Alter Chen (Ed.) Widows in India. Social neglect and public action. London: Sage.

Apt, N. (1996). Coping with old age in a changing Africa. Social change and the elderly Ghanaian. Aldershot: Avebury.

Apt, N. (1997). Ageing in Africa. Geneva: World Health Organization.
Arber, S., \& Ginn, J. (1991). Gender and later life-A sociological analysis of resources and constraints. London: Sage.

Barrientos, A. (1998). Pension reform in Latin America. Aldershot: Ashgate.

Borges-Yañez, A., \& Gómez-Dantés, H. (1998). Uso de los servicios de salud por la poblacíon de 60 años y más en México. Salud Pública de México, 40(1), 1322.

Cain, M. (1991). The activities of the elderly in rural Bangladesh. Population Studies, 45, 189-202.

Caldwell, J. (1993). Health transition: the cultural, social and behavioural determinants of health in the third world. Social Science and Medicine, 36(2), 125-135.

Cassels, A. (1995). Health sector reform: key issues in less developed countries. Journal of International Development, 7(3), 349-368.

Castells, J. (1992). Ficción y realidad de la política social para la ancianidad/1. Buenos Aires: Centro Editor de América Latina.

Chawla, S. (1996). The eradication of poverty in old age. UN Bulletin on Ageing, $2 / 3$. 
Chayovan, N. (1999). Economic well-being of Thai elderly: gender differences. Unpublished paper given at the International Conference of Women's Health, Singapore, July.

Chayovan, N., \& Knodel, J. (1997). A report on the survey of the welfare of the elderly in Thailand. Unpublished paper. Institute of Population Studies, Chulalongkorn University, Bangkok.

Chesnais, J. (1992). The demographic transition. Stages, patterns and economic implications. Oxford: Oxford University Press.

Contreras de Lehr, E. (1989). Women and old age: status of the elderly woman in Mexico. In Pan American Health Organization (Ed.) Mid-life and older women in Latin America and the Caribbean. Washington, DC: PAHO.

Derricourt, N., \& Miller, C. (1992). Empowering older people: an urgent task in an ageing world. Community Development Journal, 27(2), 117-121.

Dharmalingham, A. (1994). Old age support: expectations and experiences in a South Indian village. Population Studies, 48, 5-19.

Dinotshe Tou, S., \& Sandberg, E. (1994). The elderly and their use of the health care system. In F. Bruun, M. Mugabe, \& Y. Coombs (Eds.), The situation of the elderly in Botswana. Proceedings from an international workshop. Gabarone: National Institute for Development and Research Documentation.

Dreze, J. (1990). Widows in rural India. London School of Economics, Development Economics Research Programme DEP 26.

Dreze, J., \& Srinivasan, P. (1998). Widowhood and poverty in rural India: some inferences from household survey data. Journal of Development Economics, 54(2), 217-234.

Durán-Arenas, L., Sánchez, R., Vallejo, M., Carreón, J., \& Franco, F. (1996). Financiamiento de la atencíon a la salud de la poblacíon de la tercera edad. Salud Pública de México, 8(6), 501-512.

Featherstone, M., \& Werwick, A. (Eds.) (1995). Images of ageing. Cultural representations of later life. London: Routledge.

Fernandes, A. (1995). Cultura da crise e seguridade social: um estudo sobre as tendências da previdência e da assistência social brasiliera nos anos 80 e 90. São Paulo: Cortez.

Ferreira, M. (1999). The generosity and universality of South Africa's social pension system. The Courier, 176 (July-August).

Fletcher, A., \& Donoghue, M. (1998). Barriers to the up-take of cataract services and proposed strategies to address these. Unpublished paper. London School of Hygiene and Tropical Medicine, London.

Frenk, J., Bobadilla, J., Stern, C., Frejka, T., \& Lozano, R. (1991). Elements for a theory of the health transition. Health Transition Review, 1, 21-38.

Fries, J. (1980). Aging natural death, and the compression of morbidity. The New England Journal of Medicine, July 17.

Gorman, M. (1999a). Development and the rights of older people. In Help Age International (Ed.), The ageing and development report (pp. 3-21). London: Earthscan.

Gorman, M. (1999b). Reinforcing capability: informal community-based support services for older people in the developing world. In Help Age Interntional (Ed.), The ageing and development report (pp. 46-58). London: Earthscan.

Government of Thailand, National Statistics Office (1995). 1990 population and housing census of Thailand, Bangkok: NSO.

Grieco, M., \& Araba Apt, N. (1996). Interdependence and independence: averting the poverty of older persons in an ageing world. UN Bulletin on Ageing, 4, $10-18$.

Gulati, L., \& Rajan, S. (1999). The added years. Elderly in India and Kerala. Economic and Political Weekly, 30 October 1999, pp. 46-51.

Ham-Chande, R. (1996). Envejecimiento: una nueva dimensión de la salud en México. Salud Pública de México, 38(6), 409-418.

Hardiman, M., \& Midgley, J. (1989). The social dimensions of development. Social policy and planning in the Third World. London: Gower.

Hazan, H. (1991). Victim into sacrifice: the construction of the old as a symbolic type. Journal of Crosscultural Gerontology, 5(1), 77-84.

Hsiao, W. (1995). Abnormal economics in the health sector. Health Policy, 32, 125-139.

Ikels, C. (1993). Settling accounts: the inter-generational contract in an age of reform. In D. Davis, S. Harrell (Eds.), Chinese families in the post-Mao era. Berkeley: University of California Press.

Instituto Brasileiro de Geografia e Estatística (IBGE) (1991). Censo demográfico 1991. Número 1. Brasil. Rio de Janiero, IBGE.

International Labour Organisation (ILO) (1997). Economically active population 1950-2010. Geneva: ILO.

ILO (1992). The ILO and the elderly. Geneva: ILO.

Instituto Nacional de Estadística y Censos (INDEC) (various years) Statistical yearbook of the Argentine Republic 1998. Buenos Aires: INDEC, Buenos Aires.

Kaiser, M. (1994). Economic activities of the elderly in developing countries: myths and realities. UN Bulletin on Ageing, 2/3.

Kirk, D. (1996). Demographic transition theory. Population Studies, 50, 361-387.

Knodel, J., Chayovan, N., Graiurapong, S., \& Suraratolecha. (1999). Aging in Thailand: an overview of formal and informal support. Report No. 99-53. Comparative Study of the Elderly in Asia Research Reports, Population Studies Center, University of Michigan, Ann Arbor.

Knopoff, R. et al. (1991). Dimensiones de la vejez en la sociedad argentina. Buenos Aires: Centro Editor de América Latina.

Laczko, F. (1994). Older people in Eastern and Central Europe-The price of transition to a market economy. London: Help Age International.

Liu, X., Liang, J., \& Gu, S. (1999). Flows of social support and health status among older persons in China. Social Science and Medicine, 41(8), 11751184. 
Lloyd-Sherlock, P. (1997a). Old age and urban poverty in the developing world. The shanty towns of Buenos Aires. London: Macmillan.

Lloyd-Sherlock, P. (1997b). Healthcare provision for elderly people in Argentina: the crisis of PAMI. Social Policy and Administration, 31(4), 371-389.

Lloyd-Sherlock, P. (1999). Old age migration and poverty in the shantytowns of São Paulo Brazil. Journal of Developing Areas, 32(4), 491-514.

Lloyd-Sherlock, P. (2000a). Ageing and health policy: global perspectives. Unpublished background paper for United Nations Social Division Expert Group Meeting on sustainable social structures in a society for all ages Addis Ababa, Ethiopia, 2-5 May.

Lloyd-Sherlock, P. (2000b). Failing the needy: public social spending in Latin America. Journal of International Development, 12, 101-119.

Lloyd-Sherlock, P. (2000c). Population ageing in developed and developing regions: implications for health policy. Social Science and Medicine.

Lloyd-Sherlock, P., \& Tollman, S. (1999). The quality of life of older people in rural South Africa: relationships between public policy, economic welfare, health and social status. Unpublished research note, University of East Anglia and University of the Witwatersrand.

Londoño, J., \& Frenk, J. (2000). Structured pluralism. Towards an innovative model for health system reform in Latin America. In P. Lloyd-Sherlock (Ed.), Healthcare reform and poverty in Latin America. London: Institute of Latin American Studies.

Manton, K., Corder, L., \& Stallard, E. (1997). Chronic disability trends in elderly United States populations 1982-1994. Proceedings of the National Academy of Sciences, 94, 2593-2598.

Mesa-Lago, C. (1991). Social security: ripe for reform. In Inter-American Development Bank (IADB) Economic and social progress in Latin America. 1991. Annual report Washington, DC: IADB.

Mesa-Lago, C. (1992). Health care for the poor in Latin America and the Caribbean. Washington, DC: IADB and Pan American Health Organization.

Mesa-Lago, C. (1994). Changing social security in Latin America. Boulder: Lynne Rienner.

Mesa-Lago, C. (2000). Social assistance on pensions and health care for the poor in Latin America and the Caribbean. In N. Lustig (Ed.), Shielding the poor: social protection in the developing world. Washington, DC: Brookings Institution/Inter-American Development Bank.

Mohatle, T., \& Agyarko, R. (1999). Contributions of older people to development The South Africa study. Unpublished report, London: Help Age International.
Mupedziswa, R. (1997). AIDS and older Zimbabweans: who will care for the carers. South African Journal of Gerontology, 6(2), 9-12.

Ofstedal, M. B., Knodel, J., \& Chayovan, N. (1999). Intergenerational support and gender. A comparison of four Asian countries. Population Studies Center, University of Michigan, Comparative Study of the Elderly in Asia Report 99-54. University of Michigan, Ann Arbor, March.

Paalman, M., Bekedam, H., Hawken, L., \& Nyheim, D. (1998). A critical review of policy setting in the health sector: the methodology of the 1993 World Development Report. Health Policy and Planning, 13(1), 13-31.

Phillips, D. (2000). Family support for older persons in East Asia: durability or demise. Unpublished background paper for United Nations Social Division Expert Group Meeting on sustainable social structures in a society for all ages. Addis Ababa, Ethiopia, 2-5 May.

Redondo, N. (1990). Ancianidad y pobreza. Una investigacíon en sectores populares urbanos. Buenos Aires: Editorial Humanitas.

Rein, M., \& Worgotter, A. (1994). Labour markets and social policy in economies in transition. $U N$ Bulletin on Ageing, 2/3.

Russell, S., \& Gilson, L. (1997). User fee policies to promote health service access for the poor: a wolf in sheep's clothing? International Journal of Health Services, 27(2), 359-379.

Sagner, A., \& Mtati, R. (1999). Politics of pension sharing in urban South Africa. Ageing and Society, 19(4), 393-416.

Sidell, M. (1995). Health in old age. Myth, mystery and management. Buckingham: Open University Press.

Stocker, K., Waitzkin, H., \& Iriart, C. (1999). The exportation of managed care to Latin America. The New England Journal of Medicine, 340(14), 11311136.

Twigg, J. (1999). Obligatory medical insurance in Russia: the participants' perspective. Social Science and Medicine, 49(2), 371-382.

United Nations (UN) (1991). Intergration of ageing women in development: choice or necessity? Unpublished paper. Centre for Social Development and Humanitarian Affairs, Vienna.

UN (1994). The sex and age distribution of the world populations. The 1994 revision. New York: UN.

World Bank (1993). World development report. Investing in health. New York: Oxford University Press.

World Bank. (1994). Averting the old age crisis. Policies to protect the old and promote growth. New York: Oxford University Press. 